\title{
Evaluation of Common Activity and Life in Swedish Cohousing Units
}

This study evaluates common activity and quality of life in Swedish cohousing units to examine whether Swedish cohousing functions properly or not. A questionnaire survey was fulfilled during the autumn of 2010 in Göteborg Sweden. The subjects of study were 12 of 44 cohousing units in Sweden that included 4 of the +40 cohousing and 8 of the mixed-age cohousing. A total of 242 of 353 distributed questionnaires were collected (68.6\%) and analyzed by SPSS statistical program. The findings are as follow: 1) General characteristics of the respondents are that they are mostly healthy, evenly aged from age 50s to 70 s and highly educated with significant proportions of academics and civil workers. There are more females than males and more singles than cohabitants. 2) The most frequent and preferred common activity is a common meal followed by a coffee meeting. A common dinner, the 'hub of living together' is held almost every day or at least a few times a week. A common meal is considered one of the most important activities because of practical and social advantages in that residents can save time and cooking costs as well as engage in social contact. Referring to evaluation of frequency and content of common activity, more than a half of the respondents prefer the

\footnotetext{
Corresponding author, Professor, Dept. of Consumer \& Housing Studies, The Catholic University of Korea, 43 Jibong-ro, Bucheon, 420-743, South Korea. (jjschoi@catholic.ac.kr)

${ }^{\star}$ Emeritus Professor, Dept. of Architecture, Chalmers University of Technology, S-412 96 Göteborg Sweden. Tel: +46 295358 (jan.paulsson@2d-p.se)

This Work was supported by the Catholic University Research Fund 2011. This is a revised paper that was presented at the IAPS International symposium in Nov. 2011.

Key Words: Cohousing unit, Sweden, Common activity, Life satisfaction, Evaluation
}

current situation. 3) All of the variables (except health conditions and education level) affect participation in common activity with statistical significance. 4) Most of the respondents indicate a high level of life satisfaction and are willing to recommend others move to cohousing. They agree that there is more mutual support among residents in cohousing units than in a conventional community. In conclusion, Swedish cohousing units function successfully as they have pursued intentional community ideology and most of the residents are proud of their current living situations.

\section{INTRODUCTION}

\section{Research Background}

Cohousing is one type of intentional communities that started in Scandinavian countries where typical nuclear families have changed rapidly in comparison to other countries. An intentional community is established by a group of people with same ideas as a settlement that forms a more humane housing environment. Since the 1970s, intentional communities have been spread to North America, Europe, Australia, and Japan to meet the needs of modern lifestyles.

The history of intentional communities begin at Celtic Christian convents which were built on the shores of Ireland and Scotland during the $6-7^{\text {th }}$ century. Those were locally scattered, small sized, and mixed with males and females in the community. Though there were no festivals, they loved the earth and dreamt to be a role-model that 
could lighten the darkness of the medieval era (Dawson, 2006). In the industrial society of the $20^{\text {th }}$ century a modern intentional community movement rose again as a solution for exhausted natural resources caused by a cost-driven society and intensified individualism (Lucas, 2006). People have initiated modern intentional communities to escape from garbage, pollution, keen competition, and violence that is globally endemic in modern life.

An intentional community can be defined in diverse ways and Fromm, an American housing scholar, defines it as a new housing estate that has common facilities in the community (Fromm, 1991). According to her definition, it contains common facilities, private dwellings, resident-structured routines, management by residents, intentional design for promoting social contact, and residents' participation in a forming process as well as pragmatic and social advantages. These examples are bofollesskaber in Denmark, central living in Holland, kollektivhus in Sweden, cohousing in USA, co-operative housing in Japan and Korea, and ecovillages. These have different names, but they have common characteristics based on residents' active participation (Choi, 2008).

An investigation of an intentional community shows a few differences between ecovillage and cohousing. In the case of cohousing, a developer takes care of the main roles for planning and building construction. All of the private dwellings are designed and completed almost at the same time under a central arrangement. Potential residents are intensively involved in the design and decisionmaking processes. They stress social contacts with residents in the forming process as well as in actual living stage. Residents are responsible for spontaneous participation in common activities and mostly use a consensus decision-making method after they enter a cohousing community. With some exceptions, inhabitants in cohousing are engaged in conventional jobs in the local area and do not share income (McCarment \& Durret, 1998).

The approach of an ecovillage is recognized as more radical than cohousing. Ecovillages are very diverse in form, size and organization; in addition, it is common for residents to design and build their settlement slowly and independently. They try to make use of building materials from the local area, and it is one of the strong traditions that they build houses with reused materials as a way of forming an ecological movement. All of the housing types are various according to individual economic conditions and preference (Birgersson, 2000).

The sense of community is much stronger in an ecovillage than in cohousing. In an ecovillage, there is only a limited portion of private space. Residents share common labor and income in the community; subsequently, individual income is generally lower in a conventional society. Because of these facts, some people criticize that the concept of an evovillage shares communist characteristics (Choi, 2008; Dawson, 2006).

It is difficult to distinguish cohousing and ecovillages because some cohousers complain their communities have a weak sense of community or are too politically radical; however, some ecovillage residents agree that the cohousing model is more practical than an ecovillage since the design and development processes are simpler than in an ecovillage. Therefore, the situation becomes confusing due to an increasing tendency to develop a community combined with cohousing and ecovillage ideas (Choi, 2008). It is easy to find a cohousing with ecovillage's characteristic and vice versa.

In the "Community Directory (FIC. 2007)", approximate 700 global intentional communities are listed; however, the number of intentional communities would be more if we consider ones that belong to other organizations such as Fellowship for Intentional Community (www.ic.org), Cohousing Network (www.cohousing.org), Ecovillage Network of the Americas (www.ena/www.ecovillage.org), North West Intentional Communities Association (www.ic.org/NICA).

The intentional community movement in Korea is limited only in the establishment of ecovillages that were recently completed in farming areas. No cohousing units have been formally established and it is hard to collect information about intentional communities in Korea. Therefore, studies related to common activities in foreign intentional communities (particularly Swedish cohousing examples) could possess important instruction on how to initiate Korean cohousing in the future. 


\section{Research Purpose}

This research is to evaluate common activity and life in Swedish cohousing units to understand whether Swedish cohousing functions properly or not. Sweden is a well-known country where cohousing has been initiated and functioned for long period of time; however, limited research and evaluation exists. This research will offer empirical knowledge on residents' common activity in the context of participation, satisfaction at contents and frequency, and life satisfaction in the cohousing units. Satisfaction in common activities would affect life satisfaction in cohousing, since cohousing is a community based on active participation in common activities by residents. The enhancement of actual conditions for common activities and affecting variables can contribute to increase the quality of life for residents in the cohousing community. These results could be implemented for the future development of cohousing in Korea.

Research questions are as follows:

(1) What is the most frequent common activity in Swedish cohousing unit?

(2) How much are they satisfied at the frequency and contents of common activity?

(3) How much are they satisfied with their current living in Swedish cohousing unit?

(4) Do demographic, dwelling size and cohousing type variables affect common activity and life satisfaction?

\section{LITURATURE REVIEW}

\section{Cohousing Ideology}

The ideology of cohousing promotes common activities by residents to lessen daily chores that empowers social interaction and community security. Modern society is undergoing a transformation of the traditional family structure such as the, increase of single-person households, single-parent families, more married women participating in the labor market, and the increase of elderly families due to longer life spans. These phenomenon have limited the time for dual income and single-parent families to do daily chores and child rearing, the holistic emotional development to the only child, sense of alienation to single-person and elderly family. These social issues have emerged as typical problems in modern society. As a solution, cohousing tries to adjust the merits of the traditional extended family to modern society through the increase of intimacy among people, sense of belonging, and community security. These can be promoted through participation in common activities by residents. Cohousing has advantages from both social and practical perspectives. According to previous surveys (Choi \& Strid, 2011; Choi \& Paulsson, 2011) respondents indicated three main reasons for moving into cohousing: security, participation in common activities and preference of cohousing ideology. This result remarks that there are many people in modern society who need intimacy in the local community and common activities by residents has important meaning for the activation of the community.

The history of cohousing was detailed by a Swedish architect and professor Vestbro (1982; 1997; 1998; 2000). He described that classical cohousing was developed in the 1940s by feminists and modernists movements that aimed to lessen daily chores for married working women so that they can rest the same as men after labor hours in terms of gender equality. They expected that paid working women would put more energy into the labor market if they could rest at home as men did. Classical cohousing was a service-model that paid staff to care for house management, daily chores and child rearing; however, dwelling space was relatively small and rent was expensive. Eventually people began to criticize that cohousing was housing only for the rich and elite (Choi \& Paulsson, 2006). The self-work model evolved after the 1970s as an alternative to the service-model of modern cohousing. Residents in self-work model cohousing share daily chores on individually that is designed to save time and cost as well as empower social contact with others. It has both practical and social merit.

Modern cohousing (initiated in Denmark and Sweden) has disseminated to North America and other European countries. There are various global 
examples of cohousing communities fitted to each individual situation now. For instance, there are typical two different kinds of cohousing type according to resident's age limit in Sweden, one is the mixed-age cohousing and the other is the +40 cohousing. For the mixed-age cohousing there is no age limit for residents to move in so that diverse families (single-person households, couples with or without children, and elderly households) can reside. For senior cohousing (which is called as the ' +40 cohousing' in Sweden) residents are supposed to be at least over 40 years old without any cohabitant children. This is connected with the Swedish elderly welfare system in terms of 'Aging-in-place' (Choi \& Paulsson, 2006). The +40 cohousing in Sweden originally stems from senior cohousing where residents are supposed to be over 55 years old and is similar to other countries; however, the age limit has recently changed lately to prevent the senior cohousing community becoming too aged. The idea of the +40 cohousing is to mix residents in a way similar to the mixed-aged cohousing where residents are mixed with those working in society and those retired. Residents with different conditions can mutually support each other. For instance, the younger who are working can be supported by those retired because they have extra time to take care of cohousing as well as input their human resources and experience to the community. In addition, the younger can bring a fresh atmosphere from the outside world so that the +40 cohousing can be connected with conventional society. With this mean, they believe the +40 cohousing might be more sustainable than ordinary senior cohousing. Danish senior cohousing is also the same as the Swedish situation with a single difference in the age limit that is over 55 years old. It is affected by the elderly housing legislation to support building costs in senior cohousing.

In the 1980s, American architects McCarment and Durret, contributed to implement the Danish cohousing model in the USA as an adjusted to capitalistic society 'American Model' after they experienced living in a Danish cohousing community. Canadian cases are similar to the American model due to the political and geographical similarities. More cohousing communities have now been established in North America than in Scandinavian and other European countries (Housing Study Group, 2000; Cho et als., 2008; Choi, 2009; www.cohousing.org).

\section{Significance of Common Activities in the Community}

The participation by residents in common activities lowers community management costs and increases individual responsibility in the community because they make rules based upon self empowerment (Choi \& Paulsson, 2006). Participation in common activities also has a close relationship with the establishment of a sense of community and are complementary. The sense of community promotes participation in common activities and emotionally connects a person to the community. People feel a sense of community when they share common issues, establish confidence, and belong to a stable group. Individuals have the tendency to be mutually empathetic through sharing common emotions and expectations with others or the organization (Sarason, 1974). Common activities are a significant way to cultivate a sense of community in cohousing. Common activity in cohousing is a main drivingforce to activate community. Lee (2004) argues that a sense of community is stronger when residents belong to a similar age group, share common matters, build friendship, and are empathetic.

\section{METHODS}

\section{Research Method and Data Collection}

A questionnaire survey was carried in the autumn of 2010 in Göteborg, Sweden. A verified questionnaire that authors had designed and used in previous research (Choi \& Paulsson, 2004) was used. The questionnaire was offered in Swedish and English since some respondents preferred to reply in Swedish.

Prior to sending the questionnaire, e-mail and letters were sent to the chairpersons of all 44 cohousing units listed in the official homepage of www.kollektivhus.nu to inquire if they would like to join our research. Of those, 12 cohousing units sent back positive replies. Questionnaires were sent to 


\section{Cohousing units in Sweden}

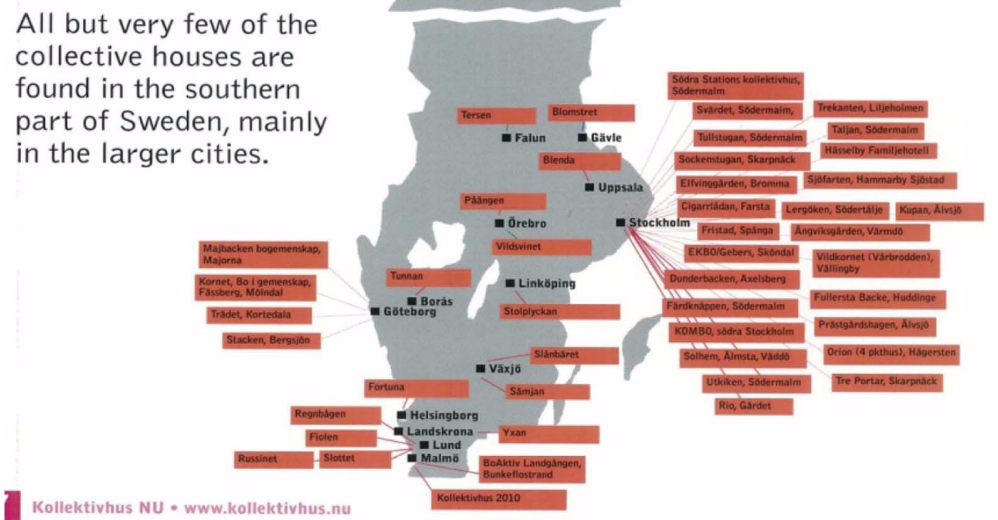

Figure 1. Distribution of Cohousing Units in Sweden (Source: www.kollektivhus.nu)

representative of 12 cohousing units by post mail for distribution to residents. For privacy reasons, the completed questionnaires were individually sent back to authors by post mail. Distributed numbers of questionnaire were intentionally controlled in consideration of numbers of units/flats and residents, in order to get similar quantity of replies so that a comparison between the mixed-age cohousing and the +40 cohousing could be made. Of total 353,165 were distributed to the +40 cohousing units and 188 to the mixed-age cohousing units. Eventually similar amounts of questionnaires were collected from the two cohousing types (127 and 115, 242 in total).

A total of 242 collected data from 353 distributed questionnaires (68.6\%) were analyzed by SPSS statistical program. Analyses of frequencies, mean comparison, t-test, anova-test, probability were used. DMR (Duncan's Multiple Range) test was added to find out if there are any differences among variables in demography, dwelling size, and cohousing type.

\section{Research Subjects}

A total of 44 cohousing units are registered in the official homepage of the Swedish cohousing organization www.kollektivhus.nu at the end of 2010; however, this number could be larger if you include those not registered. Figure 1 shows the distribution of cohousing units in Sweden and indicates that more units are established in Southern metropolitan cities and especially around the Stockholm area (www.Kollektivhus.nu). This is likely because most of Swedish population resides in 3 main metropolitan cities of Stockholm, Göteborg and Malmö, while other areas have a very low population density.

The research subjects are 12 of 44 cohousing units in Sweden that include 4 of the +40 cohousing and 8 of the mixed-age cohousing (Table 1). In Sweden, there are only 6 units of +40 cohousing, and the rest is the mixed-age cohousing. In general, the +40 cohousing units were established recently after 1994 and the mixed-age cohousing units were mostly established in the 1980s, except for Hässelby Familijehotel (1959) and Kornet (2006).

\section{RESULTS AND DISCUSSIONS}

\section{Characteristics of the Respondents}

The characteristics of the respondents are that they are mostly healthy (87.2\%), evenly aged in their 50s to 70 s, educated in high school and university (97.5\%), and significant proportions of academics (38.0\%) and civil workers (employees) with long professional education and experience (28.1\%) (Table 2). About a half (47.5\%) live in the $2 \mathrm{R}+\mathrm{K}$ dwelling. Among the respondents, there are more females (69.4\%) than males (30.1\%), and more 
Table 1. Subject Cohousing Units $f(\%)$

\begin{tabular}{|c|c|c|c|c|c|}
\hline Cohousing type & $\begin{array}{c}\text { Name } \\
\text { (Established year) }\end{array}$ & Location & Total flats & $\begin{array}{c}\text { Distributed } \\
\text { questionnaires }\end{array}$ & $\begin{array}{c}\text { Collected } \\
\text { questionnaires }\end{array}$ \\
\hline \multirow{4}{*}{$\begin{array}{l}\text { The }+40 \\
\text { Cohousing }\end{array}$} & Frdknäppen (1994) & Stockholm & 50 & 40 & 26 \\
\hline & Majbacken (2003) & Göteborg & 31 & 31 & 29 \\
\hline & Sockenstugan (1994) & Stockholm & 50 & 50 & 34 \\
\hline & Tersen (2004) & Falun & 44 & 44 & 38 \\
\hline \multirow[t]{4}{*}{ Sub Total } & & & 175 & $165(100.0 \%)$ & $127(77.0 \%)$ \\
\hline & Hässelby familjehotel (1959) & Stockholm & 40 & 20 & 20 \\
\hline & Kornet (2006) & Möndal & 44 & 44 & 31 \\
\hline & Prästgårdshagen (1987) & Stockholm & 32 & 15 & 9 \\
\hline \multirow{5}{*}{$\begin{array}{l}\text { The Mixed-age } \\
\text { Cohousing }\end{array}$} & Stacken $(1980)$ & Göteborg & 35 & 20 & 9 \\
\hline & Stolplyckans (1987) & Linköping & 49 & 20 & 8 \\
\hline & Trekanten (1986) & Stockholm & 78 & 20 & 12 \\
\hline & Trädet (1985) & Göteborg & 39 & 15 & 11 \\
\hline & Tunnan (1987) & Borås & 34 & 34 & 15 \\
\hline Sub Total & & & 351 & $188(100.0 \%)$ & $115(61.2 \%)$ \\
\hline Total & & & 526 & $353(100.0 \%)$ & $242(68.6 \%)$ \\
\hline
\end{tabular}

Table 2. Characteristics of the Respondents $n=242$

\begin{tabular}{|c|c|c|}
\hline & Variables & $f(\%)$ \\
\hline \multirow{2}{*}{ Gender } & Male & $74(30.6)$ \\
\hline & Female & $168(69.4)$ \\
\hline \multirow{3}{*}{ Age (Years Old) } & -59 & $85(35.1)$ \\
\hline & $60-69$ & 94(38.8) \\
\hline & $70-$ & $63(26.0)$ \\
\hline \multirow{2}{*}{ Living Situation } & Single & 145(59.9) \\
\hline & Cohabitant & $97(40.5)$ \\
\hline \multirow{3}{*}{ Living Period (Years) } & -3 & $74(30.6)$ \\
\hline & $3-7$ & $77(31.6)$ \\
\hline & $8-$ & 91(37.6) \\
\hline \multirow{3}{*}{ Health Condition } & Not All Right & $31(12.8)$ \\
\hline & All Right & $84(34.7)$ \\
\hline & Quite All Right & $127(52.5)$ \\
\hline \multirow{3}{*}{ Education } & Elementary School & $6(2.5)$ \\
\hline & High School & $68(28.1)$ \\
\hline & College/university & $168(69.4)$ \\
\hline \multirow{8}{*}{ Occupation } & Home Worker/family Business & $2(0.8)$ \\
\hline & Worker Without Long Professional Education & $18(7.4)$ \\
\hline & Worker With Long Professional Education & $16(6.6)$ \\
\hline & Civil Servant/official/ Employee Without Long Professional Education & $13(5.4)$ \\
\hline & Civil Servant/official/ Employee With Long Professional Education & $68(28.1)$ \\
\hline & Academic & 92(38.0) \\
\hline & Leader/owner of A Business & $14(5.8)$ \\
\hline & Others & $19(7.9)$ \\
\hline \multirow{3}{*}{ Dwelling Size } & $1 \mathrm{r}+\mathrm{k}$ & $29(12.0)$ \\
\hline & $2 \mathbf{r}+\mathbf{k}$ & 115(47.5) \\
\hline & $3 \mathrm{r}+\mathrm{k}-$ & $98(40.5)$ \\
\hline \multirow{2}{*}{ Cohousing Type } & +40 Cohousing & 127(52.5) \\
\hline & Mixed- Age Cohousing & $115(47.5)$ \\
\hline
\end{tabular}


Table 3. The Frequency of Participation in Common Activity $f(\%) n=241$

\begin{tabular}{|c|c|c|c|c|c|c|c|}
\hline $\begin{array}{ll}\text { Activity } & \text { Frequency } \\
\end{array}$ & $\begin{array}{l}\text { Every } \\
\text { Day }\end{array}$ & $\begin{array}{l}\text { Once or a Few } \\
\text { Times a Week }\end{array}$ & $\begin{array}{l}\text { Once or a Few } \\
\text { Times a Month }\end{array}$ & $\begin{array}{c}\text { Once or A Few } \\
\text { Times Per } 3 \text { Months }\end{array}$ & $\begin{array}{l}\text { Once a } \\
\text { Year }\end{array}$ & Never & Mean \\
\hline Common Meal & $49(20.2)$ & $164(67.8)$ & $21(8.7)$ & $4(1.7)$ & $1(0.4)$ & $3(1.2)$ & 5.02 \\
\hline Common Coffee Meeting & $42(17.4)$ & $78(32.2)$ & $39(16.1)$ & $32(13.2)$ & $20(8.3)$ & $31(12.8)$ & 3.99 \\
\hline $\begin{array}{l}\text { Steering Committee and } \\
\text { Inhabitants Meeting }\end{array}$ & $0(0.0)$ & $30(12.4)$ & $127(52.5)$ & $59(24.4)$ & $20(8.3)$ & $6(2.5)$ & 3.64 \\
\hline Other Activities & $6(2.5)$ & $23(9.5)$ & $83(34.3)$ & $43(17.8)$ & $35(14.5)$ & $52(21.5)$ & 3.03 \\
\hline $\begin{array}{l}\text { Common Exercise and } \\
\text { Gymnastics }\end{array}$ & $10(4.1)$ & $46(19.0)$ & $33(13.6)$ & $30(12.4)$ & $36(14.9)$ & $87(36.0)$ & 2.77 \\
\hline Common Gardening & $4(1.7)$ & $16(6.6)$ & $51(21.1)$ & $65(26.9)$ & $59(24.4)$ & $47(19.4)$ & 2.76 \\
\hline Common Hobby Activities & $3(1.2)$ & $30(12.4)$ & $50(20.7)$ & $43(17.8)$ & $52(21.5)$ & $64(26.4)$ & 2.75 \\
\hline
\end{tabular}

Total mean 23.97

Table 4. Evaluation of the Frequency and Content of Common Activity $f(\%) n=241$

\begin{tabular}{|c|c|c|c|c|c|}
\hline Content & \multicolumn{4}{|c|}{ Frequency } & Mean \\
\hline The Frequency of Common Activity & $\begin{array}{l}\text { Should be much more } \\
13(5.4)\end{array}$ & $\begin{array}{l}\text { Should be a little more } \\
65(27.0)\end{array}$ & $\begin{array}{l}\text { Just right as it is } \\
158(65.6)\end{array}$ & $\begin{array}{l}\text { Too much } \\
5(2.1)\end{array}$ & 2.36 \\
\hline The Content of Common Activity & $\begin{array}{l}\text { Yes, just as it is } \\
134(55.6)\end{array}$ & $\begin{array}{l}\text { No, I have a little other } \\
\text { interest } \\
92(38.2)\end{array}$ & $\begin{array}{l}\text { No, I have totally c } \\
- \\
15(6.2)\end{array}$ & ner interest & 2.49 \\
\hline
\end{tabular}

singles (60.0\%) than cohabitants (40.0\%). It is similar to typical the characteristics of cohousing residents identified in previous research (Ambrose, 1993; Choi 2004; Choi, 2008; FIC, 2007).

The Most Frequent Common Activity in Swedish

$$
\text { Cohousing Units }
$$

According to previous research (Cho \& Choi, 2011; Cho et al., 2008; Choi, 2008; FIC, 2007), the type of common activities in intentional community/ cohousing have been identified as similar in most of the communities. Therefore, 7 kinds of common activities (common meal, common coffee meeting, steering committee and inhabitants meeting, common exercise, common gardening, common hobby activities, and other activities) were chosen to investigate the frequency of participation (Table 3).

These activities were measured by 6 scores Likert-scale (42 scores maximum) and the scores from 23 to 28 emerged as the most common range of the total 42 . The most frequent common activity (mean 5.02 of 6.00) is revealed as the common meal followed by the common coffee meeting (mean 3.99 of 6.00). A common dinner is held almost every day or a few times a week. The common meal, the "hub of living together" is considered as one of the most important common activities in cohousing units due to practical and social advantages that residents can save time and cooking costs as well as have social contact through shared activities.

\section{Evaluation of the Frequency and Content of Common}

\section{Activity}

In the evaluation of the frequency of common activities, more than a half $(65.6 \%)$ of the respondents show "just right as it is"; however, there is need of "more than now" (32.4\%). This fact can be interpreted as most of the respondents are satisfied at the current frequency of common activity and there is an ambition to take part in more common activities (Table 4).

In regard to the contents of common activities, $55.6 \%$ of the respondents are satisfied at the current content of common activities; however, there are considerable numbers of respondents (44.4\%) who have other interests. The respondents who had other interests were asked to write down the contents of common activities that they were interested in. Those were mostly hobby programs that include movies, reading books, and painting activities. The 
Table 5. Affecting Common Activity Variables

\begin{tabular}{|c|c|c|c|c|c|}
\hline \multirow[b]{2}{*}{ Variables } & & \multirow{2}{*}{ Contents } & \multirow{2}{*}{$\begin{array}{c}\text { Participation in } \\
\text { Common Activity } \\
\text { M } \\
\text { DMR }\end{array}$} & \multirow{2}{*}{$\begin{array}{c}\begin{array}{c}\text { Evaluation of } \\
\text { Frequency }\end{array} \\
M \\
\text { DMR }\end{array}$} & \multirow{2}{*}{$\begin{array}{c}\begin{array}{c}\text { Evaluation of } \\
\text { Contents }\end{array} \\
M \\
\text { DMR }\end{array}$} \\
\hline & & & & & \\
\hline \multirow{22}{*}{$\begin{array}{l}\text { Demographic } \\
\text { Characteristics }\end{array}$} & \multirow{3}{*}{ Gender } & Male & 23.07 & 2.42 & 2.43 \\
\hline & & Female & 24.36 & 2.33 & 2.52 \\
\hline & & $\mathrm{t}$ value & $-1.612^{*}$ & 1.040 & -1.034 \\
\hline & \multirow{4}{*}{$\begin{array}{l}\text { Age } \\
\text { (Years Old) }\end{array}$} & -59 & $22.65 a$ & 2.49a & 2.42a \\
\hline & & $60-69$ & 24.15ab & $2,27 \mathrm{~b}$ & $2.46 a$ \\
\hline & & $70-$ & 25.46b & $2.30 \mathrm{~b}$ & $2.63 \mathrm{~b}$ \\
\hline & & F ratio & $4.436 * * *$ & $3.370^{* *}$ & $2.376^{*}$ \\
\hline & \multirow{3}{*}{ Living Situation } & Single & 25.17 & 2.28 & 2.51 \\
\hline & & Cohabitant & 22.15 & 2.47 & 2.47 \\
\hline & & $\mathrm{t}$ value & $4.130 * * *$ & $-2.450^{* * *}$ & .405 \\
\hline & \multirow{4}{*}{$\begin{array}{l}\text { Living Period } \\
\text { (Years) }\end{array}$} & -3 & 24.72a & 2.30 & 2.42 \\
\hline & & $3-7$ & $25.33 a$ & 2.31 & 2.57 \\
\hline & & $8-$ & $22.19 b$ & 2.44 & 2.48 \\
\hline & & F ratio & $7.560 * * *$ & 1.323 & 1.095 \\
\hline & \multirow{4}{*}{ Health Condition } & Not all right & 22.90 & 2.47 & $2.20 \mathrm{a}$ \\
\hline & & All right & 23.36 & 2.42 & $2.57 \mathrm{~b}$ \\
\hline & & Quite all right & 24.62 & 2.29 & $2.51 \mathrm{~b}$ \\
\hline & & F ratio & 1.838 & 1.595 & $4.286^{* *}$ \\
\hline & \multirow{4}{*}{ Education } & Elementary school & 27.50 & 2.20 & 2.40 \\
\hline & & High school & 23.75 & 2.49 & 2.50 \\
\hline & & College/university & 23.92 & 2.31 & 2.49 \\
\hline & & F ratio & 1.187 & 2.151 & .062 \\
\hline \multirow{4}{*}{ Dwelling Size } & \multicolumn{2}{|l|}{$1 \mathrm{R}+\mathrm{K}$} & 25.41a & $2.24 a$ & 2.52 \\
\hline & \multicolumn{2}{|l|}{$2 \mathrm{R}+\mathrm{K}$} & 25.39a & $2.27 \mathrm{a}$ & 2.51 \\
\hline & \multicolumn{2}{|l|}{$3 \mathrm{R}+\mathrm{K}-$} & $21.86 \mathrm{~b}$ & $2.49 \mathrm{~b}$ & 2.47 \\
\hline & \multicolumn{2}{|l|}{ F ratio } & $12.042 * * *$ & $3.960^{* * *}$ & .132 \\
\hline \multirow{3}{*}{ Cohousing Type } & \multicolumn{2}{|l|}{+40} & 25.18 & 2.17 & 2.48 \\
\hline & \multicolumn{2}{|l|}{ Mixed Age } & 22.62 & 2.57 & 2.50 \\
\hline & \multicolumn{2}{|l|}{ t value } & $3.544^{* * *}$ & $-5.284 * * *$ & -.255 \\
\hline
\end{tabular}

${ }^{*} \mathrm{p}<.10 ; * * \mathrm{p}<.05 ; * * * \mathrm{p}<.01$

$\mathrm{M}=$ Mean; DMR $=$ Duncan's Multiple Range test; $a, b, a b, c=$ Result of DMR test

common activity program needs to be adjusted according to the interest and needs of residents.

Table 5 indicates difference of common activities by variables that resulted from the $\mathrm{t}$-test, anova test and DMR test. This shows there are statistically significant differences by variables that influence participation in, evaluation of the frequency, and the evaluation of the contents of common activity.

All the variables for participation in common activities (except health condition and education level) affect participation in common activities with statistical significance. The groups such as female
$>$ male in gender $(\mathrm{p}<.10), 70 \mathrm{~s}->60 \mathrm{~s}>-50 \mathrm{~s}$ in their age group $(\mathrm{p}<.01)$, single $>$ cohabitant in living situation ( $\mathrm{p}<.01), 3-7 \mathrm{yr}>-3 \mathrm{yr}>8 \mathrm{yr}-$ in living period $(\mathrm{p}<.01), 1 \mathrm{R}+\mathrm{K}>2 \mathrm{R}+\mathrm{K}>3 \mathrm{R}+\mathrm{K}-$ in dwelling size $(\mathrm{p}<0.01)$, and the +40 cohousing $>$ the mixed-age cohousing in cohousing type $(\mathrm{p}<.01)$ tend to take part in common activities more often than others. The, DMR test for the variables with more than 2 groups indicates that the differences between the $-50 \mathrm{~s}$ and 70s- age group, 8yrs- and -7years in living period, $-2 \mathrm{R}+\mathrm{k}$ and $3 \mathrm{R}+\mathrm{K}-$ in dwelling size are statistically significant. For instance, people aged 
over 70s tend to participate in common activities more often than people aged younger than 60s. The people who have lived in cohousing units less than 7 years tend to take part in common activities more often than those who have lived in the community longer than 8 years. The people who live in a house smaller than $2 \mathrm{R}+\mathrm{K}$ tend to take part in common activities more often than the people who live in a house larger than $3 \mathrm{R}+\mathrm{K}$. The groups who participated in common activities often represent the characteristics of the +40 cohousing residents in terms of gender (female), age (over 70s), living situation (single), living period (less than 7 years, refer to establishment year of the +40 cohousing), dwelling size $(-2 R+K)$ and cohousing type (the +40 cohousing). It is assumed that residents of the +40 cohousing tend to participate in common activities more often than residents in mixed-aged cohousing. The reason might be that they can manage their extra time relatively freely compared to residents of mixed-age cohousing where more people have to be engaged in jobs.

The evaluation of the frequency, 4 variables (age, living situation, dwelling size and cohousing type) affect to the frequency of common activity with statistical significance. For instance, groups-50s $>$ $70 \mathrm{~s}->60 \mathrm{~s}$ in their age $(\mathrm{p}<.05)$, cohabitant $>$ single in living situation $(\mathrm{p}<.05), 3 \mathrm{R}+\mathrm{K}->2 \mathrm{R}+\mathrm{K}>1 \mathrm{R}+\mathrm{K}$ in dwelling size $(\mathrm{p}<.05)$, and the mixed-age cohousing $>$ the +40 cohousing in cohousing type $(\mathrm{p}<.01)$ tend to be more satisfied at the current frequency of common activities. In addition, the DMR test for the variables with more than 2 groups indicates that the differences between the groups of - 50s and others in their age, $3 \mathrm{R}+\mathrm{K}-$ and others in dwelling size are statistically significant (Table 5).

Groups that show a higher mean to the current frequency of common activities are almost opposite to those that show a higher mean for participation in common activities because there are more people in the mixed-age cohousing who want "just right as it is" for the frequency of common activity than in the +40 cohousing. The groups who want frequency "just right as it is" represent the general characteristics of mixed-age cohousing residents (younger, more cohabitants and a larger house). This might derive from the reason that residents in the mixed-age cohousing are mostly involved in conventional jobs and take care of the family and children, leaving them unavailable to frequently participate in common activities.

The evaluation of the contents of common activity, 2 variables as age and health condition show a statistical significance. For instance, following groups such as $70 \mathrm{~s}->60 \mathrm{~s}>-50 \mathrm{~s}$ in their age $(\mathrm{p}<.10>)$ and "all right"> "quite all right"> "not all right" in health condition $(\mathrm{p}<.05)$ tend to be more satisfied in the current contents of common activity than others. The DMR test indicates that the differences between the groups of 70s- and others in their age group from, "not all right" and others in health condition are different with statistical significance. This shows

Table 6. Evaluation of Life in Cohousing Units $f(\%) n=241$

\begin{tabular}{|c|c|c|c|c|c|}
\hline Content & \multicolumn{5}{|c|}{ Evaluation } \\
\hline $\begin{array}{l}\text { 1. How Do You 'thrive' In Your Housing } \\
\text { and Living Conditions? }\end{array}$ & $\begin{array}{l}\text { Very Good } \\
140(58.1)\end{array}$ & $\begin{array}{r}\text { Gooc } \\
98(40 .\end{array}$ & & $\begin{array}{l}\text { Not so good } \\
3(1.2)\end{array}$ & $\begin{array}{l}\text { Mean } \\
2.57 / 3.00\end{array}$ \\
\hline $\begin{array}{l}\text { 2. The Expectation You Had Before Mov- } \\
\text { ing - Have They Been Fulfilled? }\end{array}$ & $\begin{array}{l}\text { Yes, Quite All Right } \\
188(78.0)\end{array}$ & $\begin{array}{l}\text { No, Not } \\
49(20 .\end{array}$ & & $\begin{array}{l}\text { No, Far From } \\
\quad 4(1.7)\end{array}$ & $\begin{array}{c}\text { Mean } \\
2.76 / 3.00\end{array}$ \\
\hline $\begin{array}{l}\text { 3. How Is Your Present Housing and Liv- } \\
\text { ing Situation Compared To Earlier? }\end{array}$ & $\begin{array}{cc}\text { Much Better } & \text { A Little Better } \\
\mathbf{1 4 0 ( 5 7 . 9 )} & 50(20.7)\end{array}$ & $\begin{array}{l}\text { Just Similar } \\
35(14.5)\end{array}$ & $\begin{array}{l}\text { A Little Worse } \\
\text { 11(4.6) }\end{array}$ & $\begin{array}{l}\text { Much Worse } \\
5(2.1)\end{array}$ & $\begin{array}{c}\text { Mean } \\
4.28 / 5.00\end{array}$ \\
\hline $\begin{array}{l}\text { 4. If You Compare Yourself With Other } \\
\text { People of a Similar Age, How Do You } \\
\text { Compare Your Dwelling And Living Conditions? }\end{array}$ & $\begin{array}{cc}\text { Much better } & \text { A Little Better } \\
\text { 125(51.9) } & 65(27.0)\end{array}$ & $\begin{array}{l}\text { Just Similar } \\
43(17.8)\end{array}$ & $\begin{array}{l}\text { A Little Worse } \\
7(2.9)\end{array}$ & $\begin{array}{l}\text { Much Worse } \\
1(0.4)\end{array}$ & $\begin{array}{l}\text { Mean } \\
4.27 / 5.00\end{array}$ \\
\hline $\begin{array}{l}\text { 5. Would You Recommend Other People } \\
\text { Your Age Move Into Cohousing? }\end{array}$ & $\begin{array}{l}\text { Yes, Absolutely } \\
\text { 188(78.0) }\end{array}$ & $\begin{array}{r}\text { Yes, with Som } \\
52(21\end{array}$ & $\begin{array}{l}\text { Exception } \\
\text { ) }\end{array}$ & $\begin{array}{l}\text { No, Never } \\
1(0.4)\end{array}$ & $\begin{array}{c}\text { Mean } \\
2.78 / 3.00\end{array}$ \\
\hline 6. Is This Your 'Dream Living'? & $\begin{array}{l}\text { Yes, Just Right } \\
\quad 131(54.4)\end{array}$ & $\begin{array}{r}\text { No, Not } \\
107(4\end{array}$ & & $\begin{array}{l}\text { No, Far From } \\
3(1.2)\end{array}$ & $\begin{array}{l}\text { Mean } \\
2.53 / 3.00\end{array}$ \\
\hline
\end{tabular}

Total mean 19.19 
that older and healthier residents tend to be more satisfied at the current content of common activities.

\section{Evaluation of Life in Cohousing Units}

The evaluation of life satisfaction was measured by 3 and 5 scores Likert-scale for 6 contents $(22$ scores maximum). In terms of the evaluation of life in cohousing unit, most of respondents show high level of satisfaction with a total mean score of 19.99 of 22.00 (Table 6). On the whole score distribution, amazingly 22 scores of 22 occupy the highest portion showing 25\% and shows that respondents are notably satisfied at their current living in cohousing unit.

Of 6 contents of measurement, 2 contents as "expectation before moving fulfilled" (mean 2.76 of

Table 7. Variables on Life Satisfaction in Cohousing Units

\begin{tabular}{|c|c|c|c|c|c|c|c|c|}
\hline \multirow[b]{2}{*}{ Variables } & & \multirow{2}{*}{ Contents- } & \multirow{2}{*}{$\begin{array}{c}1 \\
\text { M } \\
\text { DMR }\end{array}$} & \multirow{2}{*}{$\begin{array}{c}2 \\
\mathrm{M} \\
\mathrm{DMR}\end{array}$} & \multirow{2}{*}{$\begin{array}{c}3 \\
M \\
\text { DMR }\end{array}$} & \multirow{2}{*}{$\begin{array}{c}4 \\
\mathrm{M} \\
\mathrm{DMR}\end{array}$} & \multirow{2}{*}{$\begin{array}{c}5 \\
M \\
\text { DMR }\end{array}$} & \multirow{2}{*}{$\begin{array}{c}6 \\
\mathrm{M} \\
\mathrm{DMR}\end{array}$} \\
\hline & & & & & & & & \\
\hline \multirow{21}{*}{$\begin{array}{l}\text { Demogra-phic } \\
\text { Variables }\end{array}$} & \multirow{3}{*}{ Gender } & Male & 2.56 & 2.75 & 4.18 & 4.10 & 2.74 & 2.49 \\
\hline & & Female & 2.57 & 2.77 & 4.33 & 4.33 & 2.79 & 2.55 \\
\hline & & t value & -1.314 & -.222 & -1.055 & $-2.026^{* *}$ & -.866 & -.740 \\
\hline & \multirow{4}{*}{$\begin{array}{l}\text { Age } \\
\text { (Years Old) }\end{array}$} & -59 & 2.54 & 2.75 & 4.31 & $4.05 a$ & $2.65 a$ & 2.44 \\
\hline & & $60-69$ & 2.57 & 2.76 & 4.24 & $4.36 \mathrm{~b}$ & $2.85 b$ & 2.57 \\
\hline & & $70-$ & 2.60 & 2.79 & 4.30 & $4.43 b$ & $2.83 b$ & 2.59 \\
\hline & & F ratio & .310 & .182 & .106 & $4.294 * *$ & $5.437 * * *$ & 1.952 \\
\hline & \multirow{2}{*}{$\begin{array}{l}\text { Living Situa- } \\
\text { tion }\end{array}$} & Single & 2.58 & 2.77 & 4.31 & 4.33 & 2.80 & 2.55 \\
\hline & & Cohabitant & 2.56 & 2.75 & 4.25 & 4.19 & 2.74 & 2.51 \\
\hline & \multirow{4}{*}{$\begin{array}{l}\text { Living Period } \\
\text { (Years) }\end{array}$} & -3 & 2.58 & 2.74 & 4.19 & $4.04 a$ & 2.75 & 2.48 \\
\hline & & $3-7$ & 2.65 & 2.77 & 4.22 & $4.53 b$ & 2.84 & 2.58 \\
\hline & & $8-$ & 2.49 & 2.78 & 4.41 & $4.23 \mathrm{a}$ & 2.74 & 2.53 \\
\hline & & F ratio & 1.865 & .156 & 1.126 & $6.190 * * *$ & 1.478 & .752 \\
\hline & \multirow{4}{*}{$\begin{array}{l}\text { Health } \\
\text { Condition }\end{array}$} & Not All Right & $2.48 \mathrm{a}$ & $2.52 \mathrm{a}$ & $4.00 \mathrm{a}$ & 4.06 & 2.81 & $2.32 \mathrm{a}$ \\
\hline & & All Right & $2.46 \mathrm{ab}$ & $2.80 \mathrm{~b}$ & 4.16ab & 4.30 & 2.73 & $2.48 \mathrm{ab}$ \\
\hline & & Quite All Right & $2.66 \mathrm{~b}$ & $2.80 \mathrm{~b}$ & $4.43 b$ & 4.30 & 2.80 & $2.61 b$ \\
\hline & & F Ratio & $4.426 * * *$ & $5.258 * * *$ & $3.334 * *$ & .959 & .588 & $4.538 * * *$ \\
\hline & \multirow{4}{*}{ Education } & Elementary School & $2.17 \mathrm{a}$ & 2.67 & 4.00 & 4.00 & 2.83 & 2.50 \\
\hline & & High School & $2.65 b$ & 2.85 & 4.40 & 4.25 & 2.79 & 2.57 \\
\hline & & College/university & $2.55 b$ & 2.73 & 4.25 & 4.29 & 2.77 & 2.51 \\
\hline & & F ratio & $2.691 *$ & 1.833 & .783 & .328 & .155 & .310 \\
\hline \multirow{3}{*}{$\begin{array}{l}\text { Dwelling } \\
\text { Size }\end{array}$} & $2 \mathrm{R}+\mathrm{K}$ & & 2.57 & 2.80 & 4.32 & 4.32 & 2.81 & 2.58 \\
\hline & $3 \mathrm{R}+\mathrm{K}-$ & & 2.54 & 2.74 & 4.18 & 4.17 & 2.71 & 2.46 \\
\hline & F ratio & & .764 & .906 & 1.101 & 1.053 & 1.874 & 1.566 \\
\hline \multirow{3}{*}{$\begin{array}{l}\text { Cohousing } \\
\text { Type }\end{array}$} & +40 & & 2.56 & 2.74 & 4.13 & 4.26 & 2.82 & 2.55 \\
\hline & Mixed-age & & 2.58 & 2.79 & 4.46 & 4.27 & 2.73 & 2.50 \\
\hline & t value & & -.295 & -.824 & $-2.430 * * *$ & -.037 & $1.652 *$ & .626 \\
\hline
\end{tabular}

$* \mathrm{p}<.10 ; * * \mathrm{p}<.05 ; * * * \mathrm{p}<.01$

$\mathrm{M}=$ Mean; DMR = Duncan's Multiple Range test; a,b,ab,c $=$ Result of DMR test

1. How do you thrive in your housing and living conditions?

2. The expectation you had before moving - have they been fulfilled?

3. How is your present housing and living situation compared to earlier?

4. If you compare yourself with other people of a similar age, how do compare your dwelling and living?

5. Would you recommend other people your age move into cohousing?

6. Is this your 'dream living'? 
3.00) and "recommend others to move to cohousing" (mean 2.78 of 3.00 ) with a higher agreement than others and show that residents are definitely proud of their lives in cohousing unit. This result is coincident with previous research results (Choi, 2006; Choi \& Paulsson, 2006; Cho et als., 2008).

Table 7 indicates result of $t$-test, anova test and DMR test to identify differences among affecting variables on life satisfaction in cohousing units. Of 8 variables, health condition appears as the most affecting variable for life satisfaction that shows an influence to 4 of 6 contents $(\mathrm{p}<.01-\mathrm{p}<.05)$. DMR test shows that the difference between the "not all right" and "quite all right" groups is statistically significant. For instance, the "quite all right" health group is definitely happier with their lives than others that show higher mean scores than others in all 6 contents. There are more people among the group of "quite all right" health condition than others who think their housing and living conditions are thriving, the expectations they had before moving in cohousing unit are fulfilled, their present housing and living situation is better now compared to earlier, and this is their dream living.

Followed affecting variables are age and cohousing type to 2 contents each. Age variable affects to contents of "compare one's dwelling and living with others" and "recommend others to move to cohousing". The result of the DMR test shows that there are more people among the aged over 60 s than others that think their dwelling and living are better if they compare with other people of a similar age and who recommend that other people their age to move into cohousing. The difference between the groups of aged over $60 \mathrm{~s}$ and others is statistically significant. This result could be interpreted as aged people tend to think cohousing is a good housing and living environment for their later life; however, cohousing type affects to 2 contents as "present housing and living situation compared to the nearest earlier" and "recommend others to move to cohousing". More people in the mixed-age cohousing than in the +40 cohousing think their present housing and living situation is better compared to earlier; however, more people in the +40 cohousing than in the mixed-age cohousing would recommend other people of their age move to cohousing. Gender, living period, and education affect to 1 content each, and living situation and dwelling size do not affect to any content. It means health condition is the most important factor to spend satisfied life in cohousing unit.

Concerning contents of life satisfaction measurement, "compare one's dwelling and living with others" is identified as the most influenced content by variables of gender, age, and living period, while others are influenced by less than 2 variables or none. In "compare one's dwelling and living with others" residents tend to be more satisfied with their dwelling and living compared to others such as female $>$ male in gender $(p<.05), 60 s->-50$ s in their age $(\mathrm{p}<.05), 3-7$ yrs $>$ others $(\mathrm{p}<.01)$ in living period. These groups also represent general characteristics of the +40 cohousing residents; more females, older people, a living period of 3-7 years in cohousing unit (refer to established year of the +40 cohousing). This result is the same as previous research on life satisfaction in cohousing units (Choi \& Cho, 2006; Choi, 2004, 2006).

Other indicators in the cohousing unit were measured; mutual support, plan to move out and composition of inhabitants' age group. About the mutual support in cohousing units, $95.4 \%$ of the respondents agree there is more mutual support among inhabitants in cohousing units than the conventional community with a mean score 3.66 of 4.00 (Table 8). The result represents that life in cohousing units fit the ideology of cohousing. About the plan to move out of cohousing, $56.0 \%$ of the respondents reveal they never plan to move out, followed by "a little" (39.4\%) and "a lot" (4.6\%). The people who plan to move out of cohousing "a little"

Table 8. Do You Think Neighbors Help Each Other More in Cohousing Units ? f(\%)

\begin{tabular}{ccccc}
\hline \hline Much More & A Little More & No Difference & I Don’t Know & Mean \\
\hline $177(73.4)$ & $53(22.0)$ & $4(1.7)$ & $7(2.9)$ & 3.66 \\
\hline
\end{tabular}


Table 9. Do You Have a Plan to Move from Here? f(\%)

\begin{tabular}{cccc}
\hline \hline Never & A Little & A Lot & Mean \\
\hline $135(56.0)$ & $95(39.4)$ & $11(4.6)$ & 2.51 \\
\hline
\end{tabular}

Table 10. Which do you Prefer in Composition of Age

Groups of Inhabitants in Cohousing Units? f(\%)

\begin{tabular}{cccc}
\hline \hline With Only +40 & Mixed-age & Something Else & Mean \\
\hline $114(47.5)$ & $114(47.5)$ & $12(5.0)$ & 2.42 \\
\hline
\end{tabular}

and "a lot" is $44.0 \%$. The authors of this study found that the reasons were mostly to get a bigger or newly built house among residents of the mixed-age cohousing (Table 9). The reason could be evidence that there are more residents who think of moving out from cohousing in order to meet housing needs according to the changing life-cycle among younger families in the mixed-age cohousing. The result is different from previous research where most of the respondents never plan to move out of cohousing units (Choi \& Paulsson, 2006) and the anomaly originates from the different background of the respondents that were composed of only seniors. It might be influenced by housing mobility theory that housing mobility among the elderly is relatively weaker than the younger (Choi \& Cho, 2006).

In reference to preferred composition of age group of cohousing residents, and interesting result appears as exactly the same percentages $(47.5 \%$ and $47.5 \%$ ) to each cohousing types (Table 10). It is because they prefer residents over 40 years of age in the +40 cohousing, on the contrary mixed-age residents in the mixed-age cohousing. It reveals that residents of each cohousing type are satisfied at their own age groups in the current community.

\section{CONCLUSION}

This research evaluates common activity and life in Swedish cohousing units to understand if it functions or not. 12 cohousing units were surveyed by questionnaire. The findings are as follows:

1) The most frequent common activity in Swedish cohousing units is a common meal followed by a coffee meeting. The common meal is the "hub of living together" and is considered as one of the most important common activities in cohousing units due to practical and social advantages that allow residents to save time and cooking cost as well as the opportunity to participate in social contact with others through shared activities.

The result appears in all variables (except health condition and education level) and influence participation in common activities with statistical significance. The groups that participate in common activity often represent characteristics of the +40 cohousing residents in terms of gender (female), age (over 70s), living situation (single), living period (shorter than 7 years), dwelling size (smaller house) and cohousing type (the +40 cohousing). It is assumed that residents of the +40 cohousing tend to participate in common activities more often than those in the mixed-age cohousing because they can manage their extra time relatively freely compared to the residents of the mixed-age cohousing where more people are engaged in jobs.

2) In evaluation of the frequency of common activity, most of the respondents are satisfied at current frequency of common activities and there is the desire to more frequently participate in common activities. The groups who are more satisfied at the current frequency of common activity than others represent the general characteristics of the mixedage cohousing residents because there are more people in the mixed-age cohousing who want the frequency of common activity "just right as it is" than ones in the +40 cohousing. The reason might originate because residents in the mixed-age cohousing are mostly involved in jobs or taking care of family and children, that leaves them unable to take part in common activities more frequently than now.

About a half of the respondents are satisfied at the current contents of common activity; however, there are considerable numbers of respondents who show other interests that include diverse hobby activities. In order to meet these needs, common activity programs need to be adjusted according to the interests of residents. The older and healthier tend to be more satisfied at the current content of common activities. 
3) In terms of evaluation of life in cohousing unit, most of the respondents show a high level of life satisfaction. Of 6 contents, "expectation fulfilled" and "recommend others to move into cohousing" show higher agreement than others because residents are definitely proud of their lives in cohousing unit and coincides with the results of previous research.

Among the variables, health condition appears as the most affecting variable on life satisfaction in cohousing units. Healthy residents are definitely happier with their lives than others showing higher mean scores in all contents of measurement. The second most important variable is age; the elderly seem confident that cohousing is a good housing and living solution.

Concerning contents of life satisfaction measurement," if you compare yourself with other people of a similar age, what do you think your dwelling and living conditions? " is identified as the most influenced content by gender, age, and living period variables. Coincidently with the previous research, the groups that represent general characteristics of the +40 cohousing residents show higher mean scores than others.

4) Nearly all of the respondents agree there is more mutual support among inhabitants in cohousing units than in a conventional community and reflects that life in cohousing unit fits the ideology. Slightly more than a half of the respondents never plan to move out; however, a considerable number of respondents (mostly in the mixed-age cohousing) plan to move out of cohousing units for a bigger or newly built house in order to adjust housing needs according to changing life-cycle of the younger family. In reference to preferred composition of age group of inhabitants, the residents of each cohousing type are evidently satisfied at their own age groups in the current community.

In summary, cohousing units in Sweden function successfully as they have pursued the ideology and most of the residents are notably satisfied at their current living in the community. The +40 cohousing residents are more ambitious to take part in common activities and show a higher level of life satisfaction than those of the mixed-age cohousing.
It is desirable to initiate senior cohousing unit in Korea as one of the housing alternatives so that senior residents can utilize their extra time and human resources to take part in common activities and enjoy life after retirement. For the development of cohousing types, it is recommended to facilitate both types so that residents can choose whatever they prefer since both the mixed-age cohousing and the senior cohousing have merits. For the physical building design, a flexible dwelling design from the establishment stage should be applied to meet the changing housing need of residents, especially for the mixed-age cohousing. Flexible building design contributes to the sustainability of cohousing units by decreasing frequent moving out of the community by residents.

Cultivating sense of community should be considered important if we implement the Swedish experience to initiate cohousing units in Korea. Participation in common activities in the local community could promote a sense of community.

The study subjects of this research are limited only to Sweden and one has to be careful to generalize the result of this research. The authors would like to suggest that study of international comparison including North American cohousing units would be necessary to enhance the general facts. It would be interesting to find out if there is any difference among countries or not with the previous research conducted in Scandinavian cases.

\section{ACKNOWLEDGEMENTS}

The authors would like to express great thanks to the Catholic Univ. and Chalmers which enabled us to accomplish this research. Also thanks to Prof. Peter Fröst and Marie Strid at the Institute of Healthcare Architecture in Chalmers, Prof. Dick Urban Vestbro, a chairperson of kollektivhus.nu in Sweden, and all of the respondents from 12 cohousing units.

\section{REFERENCES}

Ambrose, I. (1993), Etablering af seniorbofollesskaber, 
Erfaringer fratre projekter $i$ Odense, Statens Byggeforskningsinstitut, København, Denmark.

Birgersson, L. (2000). Konsten att ta sin plats-om Skärkäll I Bohusln (The art of taking his spot-on kärkäll in Bohuslän). Arkitektur, Chalmers Tekniska Hgskola.10-30. Göteborg, Sweden.

Choi, J. S. (2004). Evaluation of community planning and life of senior cohousing projects in Northern European Countries. European Planning Studies, 12(8), 1189-1216.

Choi, J. S. (2006). Comparison of life satisfaction between the residents of Danish and Swedish senior cohousing projects. Journal of the Korean Housing Association, 6(6), 149-161.

Choi, J. S. \& Cho, J. S. (2006). Differences between male and female in moving motivation and life satisfaction of senior cohousing residents in Scandinavia. Journal of the Korean Home Management Association, 24(1), 117-128.

Choi, J. S. \& Paulsson, J. (2006), Planning and Implementation of Scandinavian Senior Cohousing Projects, Seoul, Korea: Jipmundang Publishing Co.

Choi, J. S. \& Strid, M. (2011), Why do people move to cohousing communities in Sweden, -Differences between +40 cohousing and mixed-age cohousing-, Proceedings of IAPS International Network Symposium 2011, 152-153

Choi, J. S. \& Paulsson, J. (2011). Evaluation of common activity and life in Swedish cohousing communities, Proceedings of IAPS International Network Symposium 2011, 137-138.

Cho, J. H., Lee, D. S. \& Choi, J. S. (2008). Residents' participation and common activities in intentional community: a case of Mindlre Community. International Journal of Human Ecology. 9(2), 107-116.

Choi, J. S. (2008). Characteristics of community life in foreign intentional communities focus on the differences between ecovillage and cohousing. International Journal of Human Ecology 9(2), 93-105.

Cho, J. H. \& Choi, J. S. (2011). A study on residentsí participation and the characteristics of cohousing in USA. Journal of the Korean Housing Association, 22(2), 11-20.
Dawson, J. (2006). Ecovillages, New frontiers for sustainability. UK: Green Books Ltd.

FIC (2007). Community Directory (2007). USA: Rutlege. Fromm, D. (1991). Collaborative Communities, Cohousing, Central Living, and other New Forms of Housing with Shared Facilities. New York: Van Nostrand Reinhold.

Housing Study Group (2000). Cohousing in the World. Seoul, Korea: Kyomunsa Publishing Co.

Lee, H. J. (2004), Provision of affordable housing for urban seniors in a new local era, Journal of the Architectural Institute of Korea, 6(2), 1-9.

Lucas, C. (2006). Forward of ecovillages, by Dawson, New Frontiers for Sustainability.UK: Green Books Ltd. UK.

McCarment, K. \& Durret, C. (1998), Cohousing, a Contemporary Approach to Housing Ourselves, Berkely, CA: Ten Speed Press.

Sarason, S. B. (1974), The Psychological Sense of Community: Prospects for a Community Psychology, San Francisco, USA: Bookline Books.

Vestbro, D. U. (1982). Kollektivhus frn enkokshus till bogemenskap, Stockholm, Sweden Byggforskingningsrdet 28, 1982.

Vestbro, D. U. (1997). Collective housing in Scandinavia -how feminism revised a modernist experiment, Journal of Architectural and Planning Research 14(4), 329-342.

Vestbro, D. U. (1998), The Study of Collective Housing: A Swedish Perspective, The Meaning and Use of Housing Edited by Ernesto G. Arias, Avebury, USA: 405-424.

Vestbro, D. U. (2000). From collective housing to cohousing -a summary of research, Journal of Architectural and Planning Research, 17(2), 164-177.

www.kollektivhus.nu

http://hem.www.fyristorg.comñKollektivhus och Ekobyar in Sverige

Received August 16, 2011

Revised November6, 2011

Accepted November 21, 2011 